\title{
Unable to Position Lead In tributary Vein of Coronary Sinus
}

National Cancer Institute

\section{Source}

National Cancer Institute. Unable to Position Lead In tributary Vein of Coronary Sinus. NCI Thesaurus. Code C100029.

The coronary sinus / left ventricular lead was not implanted because the operator was unable to position the lead in the tributary vein of the coronary sinus. (ACC) 